Vol. 5, No. 2, 2019

Roman Frankiv

\title{
THEORETICAL AND TERMINOLOGICAL BASES FOR DEFINITION OF NEO-MODERNIST ARCHITECTURE IN LVIV
}

\author{
Associate Professor of the Department of Design and Basics of Architecture \\ Lviv Polytechnic National University \\ romanfrankiv@gmail.com \\ ORCID 0000-0003-1100-0930
}

Received: 05.09.2019/ Revised: 14.10.2019 / Accepted: 25.10.2019

C Frankiv R., 2019

Abstract. The article considers a problem of terminological determination of architectural objects of neo-modernism on the example of Lviv architecture, social and cultural preconditions and factors that influenced the formation of the neo-modern language at the turn of the XX-XXI centuries.

Key words: neo-modernism, late modernism, liquid modernism, Lviv architecture.

\section{Introduction}

The various phases of the modernization process, which continues from the eighteenth century, have also become a source of architectural development, which has undergone several stages of modernization. After conceptualization period at the turn of the nineteenth and twentieth centuries, now it is possible to distinguish two phases of the theoretically well-developed directions - "modernism" and "postmodernity". However, after modernization resources of both were exhausted, new design techniques, that received different terminological definitions, began to gain popularity. Since in all cases it is a set of the same techniques, we can speak of the problem of defining a single optimal term that can outline the architecture in current phase of modernization.

Architecture development associated with the processes of modernization has already passed several fundamental phases, which in general, are confined to the concepts of "modernism" and "postmodern". However, at the end of the twentieth century, some objects, which could not be attributed to either (the first or the second category) began to gain popularity. Consider the critique of the "high modernism" architectural design and disadvantages of "postmodern", buildings of this nature have their own concept of shape. Due to historical circumstances of architecture in Lviv, all phases of modernization seemed to oscillate between extremes - modernism in the form of Soviet typical or neo-constructivist design and postmodern demodernization. During the 2010-s, there was a rapid transition to a new interpretation of avant-garde principles in design and arose a new architectural language that needed its own study and determination.

\section{Results and Discussion}

Diversity and dynamism that became main characteristic of architecture on the turn of XX-XXI centuries, greatly enriched the spatial environment of cities, but on the other hand - caused a reflection crisis about the objects created during this period in terms of architectural theory. Spatial solutions and ideology of new projects could not fully fit into either the well-developed theoretical framework of postmodernism or the previous 
system of modernism with which they had much in common. Early postmodern ideologues such as Robert Venturi and Charles Jenks, in their descriptions of modernism, grounded on that fact that styles and ideologys evolved linearly, changing one another. In this sense, postmodernism was seen as the end of modernism, and transition to a certain universal state of synthesis and hybridization, within which the role of architecture as "communication" changes its role as "function". Since "communication" in a free society has a high degree of freedom, postmodernism claimed itself a "final" status as a space of endless intellectual play, without the necessary ideological and formal frameworks. At the same time, early theorists of postmodernism too attached it to the rehabilitation of pre-modern images, which became the main pillars of the "communicative" mission of architecture. On the other hand, the criticism and denial of modernism has become a necessary attribute of postmodern discourse, taking on the form of ideological dogma, which contradicted the declared essence of postmodernity as a de-ideologized creativity. It is worth noting, however, that within the self-awareness of the early postmodernist, he contradicted modernism, not as an equivalent doctrine, but as a return to the "communicative" role of architecture as a "language" eliminated previously by modernism. In this sense, "silent" modernism was not forbidden, but simply disappears, being filled with "language" of the postmodern. In this regard, continued existence of modernist architecture in the early postmodern period, was seen by the latter as a kind of residual phenomenon, from which become its designation as "Late modernism". The concept of "Late modernism" was introduced by Charles Jenks - one of the leading theorists of the early postmodern, who dedicated to it a separate book (Jencks, 1980). However, Jenks has already noted that "late modernism" is not a simple inertial phenomenon, but one of the attempts to answer the problems of modernism. In the 1970-s became known the projects of the so-called New York 5 Group (Hays, 1988), in which the modernist form was used not only to provide the most rational function, but also as a means of constructing a pathos. Unlike postmodern objects, in which sources of "language" and "communicativeness" acted via historical architecture motifs, some members of the New York group began to use abstract geometric forms as a means of "communicativeness". In this sense, they returned to the origins of abstract art, such as the work of the De Stijl group (Denker, 1982). As a result, abstractionist aesthetics were released once again from attachment to function and became a self-contained artistic language, as it was at the beginning of the age of abstract art, which makes the term "late modernism" no longer appropriate. Rather, it is possible to speak of the revival of "pre-functionalist" modernism, linked to the original theory of avantgarde "art for the sake of art" (Edwards, 2006).

During the 1980-90s, it became clear that the predictions of postmodern theorists about the gradual disappearance of modernism were not come true. Modernist architectural language continued to exist, gradually moving away from the features that were the subject of criticism in the late 1960s. In 2000, sociologist Sigmund Bauman proposed the use of the term "liquid modernism" (Bauman, 2000). Bauman saw "liquid modernism" as a chaotic continuation of modernism, characterized by a sense of insecurity, the variability of social roles and positions. The situation of "liquid modernity" requires the person to take responsibility for his choice, contribution to social life and development (Bauman, 2000). The leading categories are temporality instead of permanence, variability instead of static. The predetermined being order, becomes the object of self "existential" construction by the individuals (Phillips, 1994). Around the same time, also appears a concept of "reflexive modernism", which was proposed by Anthony Giddens, Ulrich Beck, and Scott Lesh (Beck, U., Giddens A., Lash S., 1994). In their understanding, the "reflexivity" of modernism comes when "high" modernism achieves all its objectives, derived from such features as universal education, the welfare state, civil and universal political rights. When completed, these progressive qualities become objects of mutation and rethinking (Chanqi, 2012). The traditional nation-state, family, religiosity dissolve under the pressure of two forces individualization and globalization (Larry, 2007).

Another notional framework of modernist architecture, which continued to exist despite the criticism by postmodernists, is the concept of "neo-modernism". The neo-modernist ideology based on preservation of the rationalistic priorities and abstract symbolism (Szyjkowska-Piotrowska, 2016), which, however, are combined with irrationality, spontaneity and limited expressiveness. Unlike modernism, neo-modernism recognizes the value of personality and individuality, without considering it merely as part of an abstract system. At the same time, neomodernism undermines postmodern perceptions of the relativity of all values and tends to systematize them on an 
appraisal principle. In this regard, although neo-modernism recognizes the informational singularity and the inability to reach for person, or even a certain collectives all knowledge, he nevertheless tends to create such content that takes the form as a "last word" (Correia, 2011).

In the context of modernization theory, the changes that are considered is about transition phase from so-called Third Industrial Revolution (1947-1970) to the Fourth (1970 - probably 2020). The latter characterized by informatization, by networking and a knowledge-based economy (Research Group for China Modernization Strategies, 2006). In this sense, it is worth noting the mutual correspondence of the modernization phases theory and the early postmodern theorists interpretations, who were contemporaries of the transition of the industrial phase to the information phase. If during the period 1947-1970 there was a process of automation of (already industrialized) production, one can understand the perception of abstract aesthetics of "high modernism" as a value, and its depreciation in the early stages of the network "communicative" society, which began to perceive architecture as not a "function" but as a "language". However, in this case, neo-modernism no longer acts as an inertial remnant of a phenomenon that belongs to the past, but simply as an architectural expression of a more recent stage of modernization. In other words, it can be said that the predictions of early postmodern theorists the end of modernism, in fact, was only its transformation, and postmodern itself, a short period of "reaction", or in general the most archaic form of communicative architecture, the development of which continued to take place in modernism strata.

A separate aspect of modernist design terminology of the XX-XXI centuris boundary, is that they consider issues existing in a broad socio - cultural context. Neo-modernism, in this case, is perceived as a material expression of the broader phenomenon of changing relationships and political changing in society and its orientation. Avant-garde in architecture, traditionally associated with liberal and socially-oriented public inquiry (the most striking example of which can be the work of Robert van Hoff) (Vermeulen, 1986). "Classical" architecture, on the contrary, has often become a way of materialization of totalitarian and hierarchical systems. In this sense, however, it is difficult to relate the revival of hierarchy and traditionalism whith the revival of traditionalist morphology in the postmodern era. The "Student revolution" of 1968, one of the important links in the birth of postmodern, on the contrary, emphasized the inadmissibility of any violence, advocated the full freedom of choice and respect for the individual (Croker, R., Dychtwald, K, 2007). Therefore, the postmodern wave of traditionalist morphology should be linked rather to the shifting of modernism from the "obligatory" category to the free choice category.

In Lviv`s architecture, the sequence of "modernism" - "postmodern" - "neomodernism" had a pronounced character due to the underlined sharpening of the features inherent in each of these tendencies. As the consideration of the modern stratum goes beyond the thematic limits of this article, it is only necessary to note that it presented mainly by extremely pragmatic examples of typical Soviet architecture and a number of representative objects made by modernist manner individual projects in a, sometimes with neo- constructivism elements. Soviet construction of the 1980s-90s was a kind of extreme rationalism, which became especially vulnerable to growing postmodernists criticism (who in the Soviet and post-Soviet space were more latent than open-minded). During the 1990s, in the wake of this criticism, a period of radical demodernization of architecture begun. That is way such architecture where associated with the particular "seriousness" of the postmodern stage in the history of Lviv (and generally post-Soviet) architecture - the lack of irony, game of meanings, easies, theatricality (Mizrakhi M., 2010). Very often projects looked like a stylization of industrial materials and construction under certain patterns of traditionalist culture of feudal historical periods. Not literally reproducing the proportions and decorative techniques of pre-modern styles, the design solutions used specific "demodernization" elements - towers, arches, sloping roofs, rust and more. This wave of "demodernization" was a natural reaction to the pseudo-modernization experience of the socialist countries, in which the development of industry and universal education was not accompanied by the expansion of the civil and political rights of society. Thus, the attention and expectation of greater freedom, both in the Western and post-socialist world, was re-focused on the past, but if in the first case it was only to unburden the framework of modernism itself, then in the second - a full-fledged belief in the utopia of the past, as a more perfect and effective system of social relationships. The low number of new construction in Lviv during the 1990s and 
2000s, however, did not allow this demodernization trend to develop in full extent. This time, single residential, banking and sacral objects were created, some houses into historic aeries. A wave of neo-modern architecture associated with the mass-construction revival of in Lviv during the 2010s. Objects that can be classified as neomodernistic are characterized by a return to the original principles of avant-garde art, without being bound by the formula "form follows function". Research of project practice specifics in Lviv suggests that the change in the architectural paradigm was due to two major factors. Firstly, these are the requirements of an increasingly competitive real estate market, in the context of which there was a need for the "legalization" of residential buildings, which became appropriated with attractive names and spatial images. Secondly, the acquaintanceship of local architects to the neo-modern architecture of Western Europe, which has already passed the postmodern stage and developed the language of a new, more liberated modernism, played an important role.

There are two main types of neo-modern objects, that emerged in Lviv architecture during this period. The first, is characterized by a clear rectangular geometry, in which the architectural image is formed by a series of irregular compositional nuances. With their help is possible to avoid the predictability and monotony effect inherent from "heroic modernism" and create a richer three-dimensional environment (Fig. 1). This type of neo-modern architecture is also (to some extent), approximated to the constructivist design method, which was characterized by the design of certain functional elements, to enhance the architectural image of the structure. Thus, the effect of compliance with the principle of "shape follows function" is achieved, but the possibilities of shaping are greatly expanded. In Ukrainian architecture of the Independence period, this way of design first became widespread in the construction practice of Dnipropetrovsk in the 2000s. This kind of architectural solution, although they mostly lack outstanding artistic qualities, and do not serve the accents that dominate the space, nevertheless, create a rich background environment and depart significantly from the inertia of the typical and normative design of the Soviet era, which was still preserved in Lviv architecture of the postmodern period.
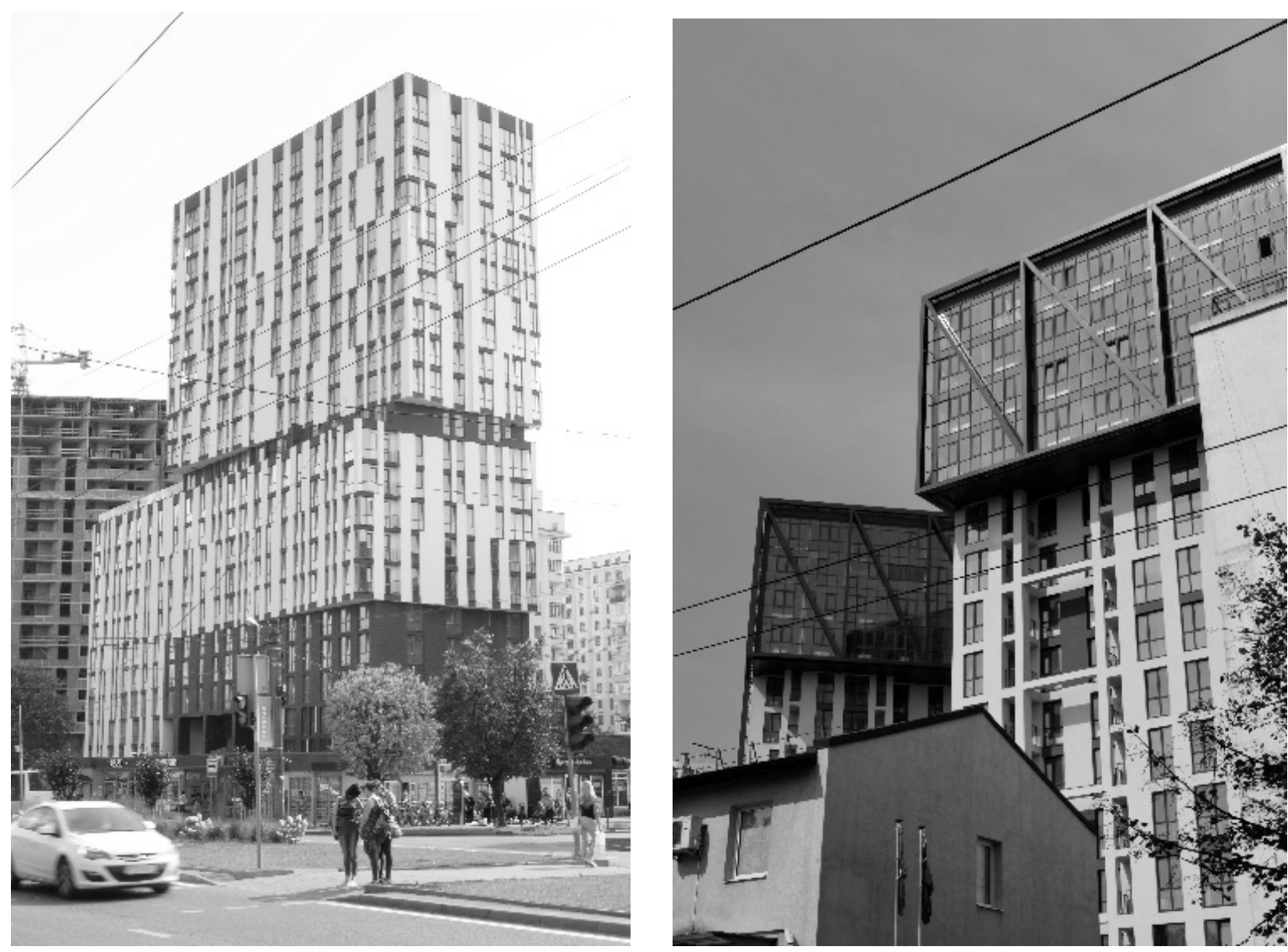

Fig. 1. Apartament buildings on the UPA Heroes street and Chornovil Avenue (design of "AVR Development") 

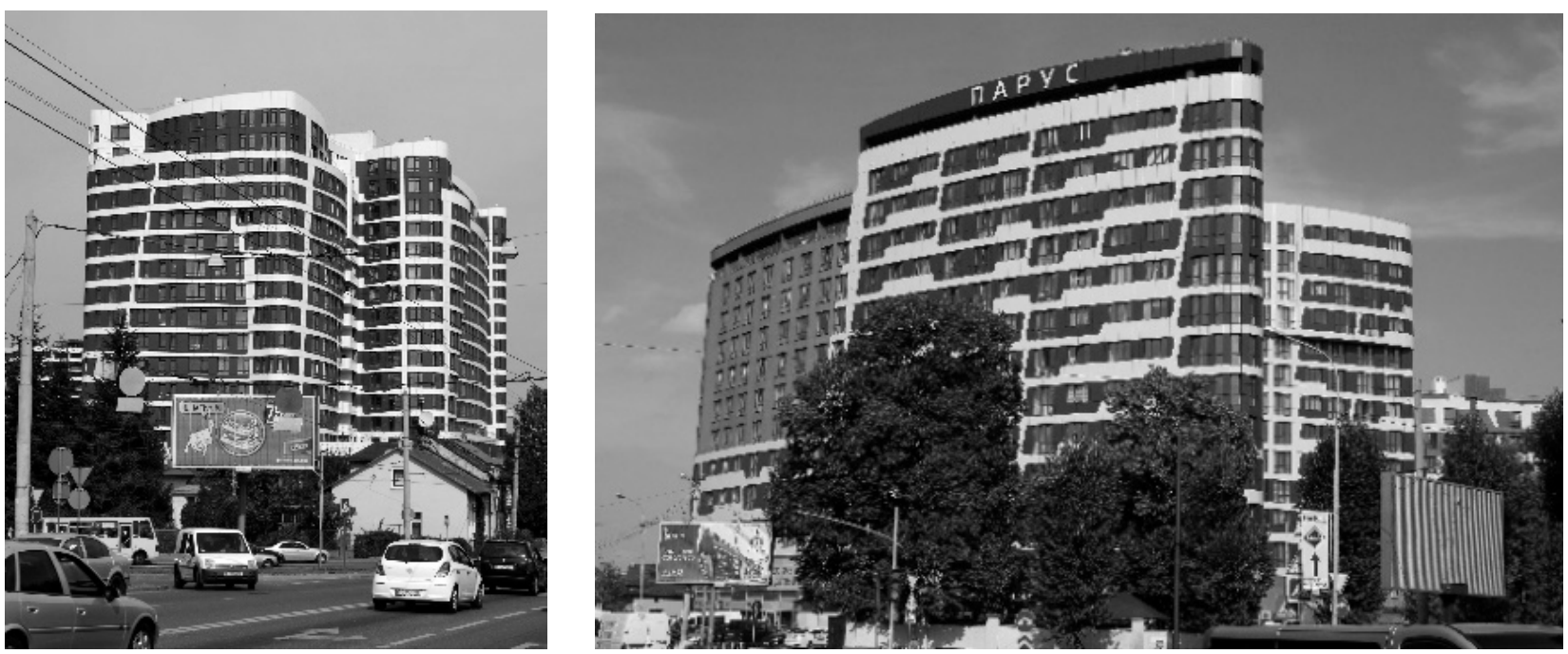

Fig. 2. Apartament buildings on Lypynskoho and Kulparkivska streets (design by Igor Gryzliuk)

Second type of Lviv neo-modern objects are dynamic compositions in which the purpose of creating a charismatic image is somewhat outweighed a logic of purely functional morphology. It should be said, that here, in greater extent, is seen attempts to interpret the architectural form as "language", as postmodernists did in the past, but unlike the latter, this "language" creates by means of avant-garde visual culture, without naturalistic and classical order quotations. The architecture of such structures represent a spatial way of constructing pathos, the main means of which are: large scale, contrasting color and plastic mass (Fig. 2).

Due to the rapid development of neo-modernism in Lviv architecture (which has no analogues in other cities of the Western region of Ukraine), one should pay attention to the worldview aspects of this phenomenon. It`s been said before that the sequence of "modernism" - "postmodern" - "neo-modernism" is a chain of constant modernization, which moves in the direction of constant liberation from various kinds of restrictions from ideological to technological. At the stage of neo-modernism, we can note:

1) Tendency to be exempt from the influence of political and cultural institutions;

2) Critics of liberalism as a kind of new "compulsory" ideological system of views.

Although liberalism was imagined as an area of ultimate freedom, it also appeared to have limitations. Argentine political researcher Carlos Escude describes the content of these borders. He writes that humanity must resolve the dilemma - if all cultures are morally equal, then all human individuals do not have equal rights, because some cultures, for example, give men more rights than women. If, on the other hand, men and women are endowed with the same human rights, then all cultures are not morally equal, because cultures that recognize that "all people are created equal" should be considered "higher", more developed than those who don't think so (Escude C. 2006).

The era of neo-modernism, in this context, tends more clearly articulate its own self-sufficiency and absoluteness, that's why it partly, return to the ideology of "heroic" modernism. For the specifics of Lviv (as well as the post-Soviet context in general), an important sign was the partial abandonment of the utopia of the past, and returning to a positive perception of the present and future. In this regard, postmodern aesthetics, which has here a signs of demodernization, was largely marginalized and pushed off from the mainstream. Neo-modern objects began to emerge, even in the historical environment, harmonization of which with the surrounding context carried out through the techniques of abstract art and not historical mimicry. Considering the specific socio-cultural phenomena that contributed to the development of neomodern discourse in Lviv, we can note the following processes. In the context of protest against traditional cultural and political establishment, it is possible to note the important place that the city played in the mass protest during the Euromaidan in 2013-14, the developed network of civil society organizations, the absence of dominant influence of major oligarchic actors in the region and so on. Regarding to neo-modern rethinking of liberalism, throughout the period 1990-2010, city was a symbiosis of liberal domestic culture 
(tolerant attitude to ethnic and linguistic minorities, heterogeneous cultural heritage, etc.) and traditionalist models of collective behavior (mass religious processions, regional ethnographic customs, etc.). In this sense, we can state that both trends manifested themselves in Lviv with particular intensity, why the surge in neo-modern architecture does not seem casual here.

\section{Conclusions}

- Within the modernization process, were formed several terminological definitions of the period and architecture on the turn of the XX-XXI centuries. In particular, "late modernism", "current modernism", "neomodernism". Each of them based on their own understanding of design ideological principles development and meaning of architectural form for society. Despite attempts to substantiate each of this definitions by a significant number of cultural and scientific studies as well as practical arguments, not all of them equally convey the content of the architectural phenomenon of a new interpretation of modernist morphology. The most adequate definition can be considered a term "neo-modernism".

- Neo-modernism in the broader context can be attributed to: a) a tendency to release itself from the influence of political and cultural institutions, and b) moderate criticism of liberalism, as a kind of new "compulsory" ideological system of views. In the Lviv context, in the first case, it is worth noting the important place that the city played in the popular speeches during the Euromaidan in 2013-14, the developed network of civil society organizations, the absence in the region of the dominant influence of major oligarchic actors, etc. In the second case, throughout the period of 1990-2010, city was a symbiosis of liberal domestic culture (tolerance of ethnic and linguistic minorities, heterogeneous cultural heritage, etc.) and traditionalist models of collective behavior (mass religious processions, regional ethnography, etc).

- There are two main types of neo-modern objects, that emerged in Lviv architecture during this period. The first of them is characterized by a clear rectangular geometry, in which the architectural image is formed by a series of irregular compositional nuances. Second type of Lviv neo-modern objects are dynamic compositions in which the purpose of creating a charismatic image is somewhat outweighed a logic of purely functional morphology. It can be said that, that such kind of attempts have been made to interpret the architectural form as "language", as postmodernists did in the past, but unlike the latter, this "language" is created by means of avantgarde visual culture, without naturalistic and classical order quotations. The architecture of such structures is a peculiar spatial way of constructing pathos, the main means of which are: large scale, contrasting color and plastic mass.

\section{References}

[1] Jencks Ch. (1980). Late-Modern Architecture, Rizzoli, NY

[2] Hays, K. M. (1988). Architecture Theory since 1968. Cambridge, MA: The MIT Press. p. 239-240.

[3] Denker S. (1982). "De Stijl: 1917-1931, Visions of Utopia”. Art Journal. 42 (3): 242-246

[4] Edwards O. (2006). "Refined Palette". Smithsonian Magazine: April 29

[5] Bauman Z. (2000). Liquid Modernity. Cambridge: Polity

[6] Phillips A. (1994). On Flirtation Harvard: Harvard University Press, - p. 124

[7] Beck, U., Giddens A., Lash S. (1994). Reflexive Modernization. Politics, Tradition and Aesthetics in the Modern Social Order. Palo Alto: Stanford University Press

[8] Chanqi H. (2012). Modernization Science: The princeples and methods of national advancement. Berlin: Springer Science \& Business Media - p. 111

[9] Larry J. R. (2007). Globalization and Everyday Life, London: Routledge - p. 57

[10] Szyjkowska-Piotrowska A. 2016. Neo/modernism - philosophical awareness in art, Łódz: Łódzkie Towarzystwo Naukowe.

[11] Correia C. J. (2011). Modernism and Neomodernism. Notes on the nature of art. In Dichten und Denken. Perspectiven zur Ästhetik, ed. Tobias Dangel, Cem Kömürcü e Stephan Zimmermann., 113-128 .

[12] Research Group for China Modernization Strategies (2006). China Modernization Report 2006: Social Modernization. Beijing: Peking University Press. 
[13] Vermeulen E. (1986). "van 't Hoff”. In Blotkamp, Carel (ed.). De Stijl: The Formative Years 1917-1922. trans. Loeb, Charlotte I.; Loeb, Arthur L. Cambridge, Massachusetts: MIT Press, pp. 206-220.

[14] Croker R. (2007). The Boomer Century, New York: Springboard Press, p. 32, p. 124

[15] Mizrakhi M. (2010). Gra yak atrybut postmodernyh komunikacij [Tekst]: avtoref. dys. kand. kul turologiyi : 26.00 .01 / Mizrakhi Mariya Vasyl`ivna ; Tavr. nac. un-t im. V. I. Vernads`kogo. Simf. 19 s.

[16] Escude C. 2006. Hacia un nuevo Medievo? El neomodernismo frente al conflicto global actual; Universidad del CEMA, Area de Ciencia Politica No. 330, p. 3

\author{
Франків Роман
}

\title{
ТЕОРЕТИЧНІ І ТЕРМІНОЛОГІЧНІ ОСНОВИ ВИЗНАЧЕННЯ НЕОМОДЕРНІСТСЬКОЇ АРХІТЕКТУРИ У ЛЬВОВІ
}

\begin{abstract}
Анотація. Різні фази процесу модернізаиії, котрий триває від XVIII століття, стали також джерелом архітектурного розвитку, що пройшов кілька стадій осучаснення. Після періоду концептуалізачї на межі XIX-XX століть можна виділити дві фази теоретично добре розроблених напрямки “модернізму” та “постмодерну”. Однак після вичерпання обидвома напрямками свого модернізаційного ресурсу, стали набирати популярності проектні прийоми, які отримали різну термінологічну детермінацію. Оскільки у всіх випадках ідеться про набір одних і тих самих прийомів, можна говорити про існування проблеми окреслення єдиного оптимального термін, яким можна окреслити архітектуру на сучасній фазі модернізації. Врахувавши критику архітектурного формотворення періоду “високого модернізму” та недоліки “постмодерну”, будівлі такого характеру мають свою власну концепцію формотворення. В силу історичних обставин в архітектурі Львова всі фази модернізації мали вигляд коливання між крайностями - модернізму у вигляді радянського типового та неоконструктивістського про'ктування та постмодерною демодернізацією. Впродовж 2010-х років тут відбувся стрімкий перехід до нової інтерпретації авангардних принципів у проектуванні $і$ розвилась нова архітектурна мова, щзо потребує свого вивчення та кваліфікації.

Розглянуто проблему термінологічного визначення сучасних об'єктів модерністської архітектурної мови на прикладі Львова. Визначається сочіальні та культурні передумови і фактори, щзо вплинули на ї̈ формування. В изьому контексті аргументовано використання терміну неомодернізм, як поняття, щзо найбільш наближено до змісту розглянутих архітектурних явищ. Виділено два основні типи неомодерних об'єктів, що виникли у львівській архітектурі в цей період. Перший з них характеризується чіткою прямокутною геометрією, в якій архітектурний образ формується низкою композиційних нюансів. Другий тип львівських неомодерних об'єктів - ие динамічні композиції, в яких мета створення харизматичного образу дещо переважає логіку суто функиіональної морфології. Можна сказати, щзо подібного роду спроби інтерпретують архітектурну форму як “мову”, як ие робили постмодерністи в минулому, але на відміну від останньої, ия “мова” створюється за допомогою авангардної візуальної культури, без натуралістичних та класичних пропозицій. Архітектура таких споруд - це своєрідний просторовий спосіб побудови пафосу, основними засобами якого є: великі масштаби, контрастний колір та пластична маса. Було визначено, шьо неомодернізм у ширшому соиіокультурному сенсі можна віднести до: а) тенденції звільнення від впливу політичних та культурних інститутів (“істеблішменту”) та б) помірної критики лібералізму, як свого роду нової “примусової” ідеологічної системи поглядів. У львівському контексті, у першому випадку, варто відзначити важливе місие, яке місто відігравало у популярних виступах під час Євромайдану у 2013-14 роках, розвинуту мережу організаиій громадянського суспільства, відсутність y регіоні домінуючого впливу у великих випадках олігархічних діячів тощо. У другому випадку місто протягом усього 1990-2010 рр. місто було симбіозом ліберальної вітчизняної культури (толерантність до етнічних та мовних меншин, неоднорідна культурна спадщина тощо) та традиціоналістичних моделей колективної поведінки (масові релігійні ходи, регіональна етнографія тощь).
\end{abstract}

Ключові слова: неомодернізм, пізній модернізм, текучий модернізм, архітектура Львова. 